\title{
BRIEF INTRODUCTION ON THE INTERNATIONAL IMPACTS OF THE 2020 PANDEMIC: CONTRIBUTION TO A STRATEGIC ANALYSIS
}

\section{Paulo Fagundes Visentini Coordinator, NERINT/UFRGS}

The origins of the current pandemic are wrapped up in conspiracy theories, but what is known is that it reached the foundations of the world system based on economic globalisation, reinforcing national and social antagonisms. Analysing the situation during its unpredictable evolution is risky, but the costs of not trying are even greater, given the prevailing confusion and manipulation. The dimensions and speed of the spread of the virus are unprecedented, since the world is much more urbanised and connected than in previous pandemics. Dominant strategies and narratives simply lost their meaning, leaving a vacuum that is filled by short-term reactive actions. But is hard politics paralysed, or the crisis creates conditions for projects to be implemented almost without opposition?

\section{The crisis deepened even before the pandemic}

The analyst must always focus on the context in which the studied object or process is found, particularly the preceding situation, to assess its likely impact. Since 2009 there has been an American and British reaction in response to the subprime and Eurozone crisis, first with Barack Obama and then with Donald Trump. It consisted of more neoliberalism at the domestic level and new forms of conflict at the international level. Donald Trump did not create the agenda, he just assumed it with a business logic and without the diplomatic and multilateral rhetoric of the Democrats, who also defend America First. For almost two years, global economic growth has been dwindling, a phenomenon that was intensified in 2020 , threatening the economic recovery of the Trump administration - who is running for reelection. 
In the pre-pandemic world we witnessed Brexit, the attempted Colour Revolution in Hong Kong and the taxation of Chinese - in addition to pressures against $5 \mathrm{G}$ technology - and Franco-German products by the United States. Massive protests were also taking place in Colombia, Ecuador, Chile, Lebanon and Iraq, which could be contained or even intensify after the quarantine period. The embargoes against Iran and Venezuela, the arms and oil pressure against Russia (with the drop in prices before the pandemic) and the progressive depletion of the multilateral political and economic system were also extended. The alleged American gains in recent years, in addition to the weakening of the international foundations on which Washington's leadership itself is based, have been drained by the economic recession caused by the rapid advance of the pandemic in the US.

During the previous decade, societies were fragmented politically and socially and became ideologically disoriented through the so-called technological "social" networks. The rapid advancement of labour by mobile applications and the subcontracting of self-employed workers (the so-called "entrepreneurs") fragmented the labour world to such an extent that the volume of financial aid needed by precarious people during the pandemic surprised governments worldwide. Virtual contact between people, through monitored and inductive networks, diluted any form of effective collective political action. Much of the social life has become virtual and political participation has become electronic and innocuous, mixing fantasy and reality: Orwell's 1984 merged with Huxley's Brave New World in a murky scenario.

In a recent interview, Noam Chomsky said he believed that a "Conservative International" was being formed, opposing the emergence of a "Progressive International". The latter would be based on progressive personalities, such as Bernie Sanders, states that provide material (China) or medical (Cuba) support, and the civil society, driven by solidarity initiatives (which, in fact, are a minority). All in opposition to the conservative leaders of the US, Eastern Europe and India, among others. The problem is that many believe it to be enough just to share messages of support to a "politically correct" initiative for it to become reality.

Chomsky is well-known for his critical and ethical worldview, but also for being guided by a "magical thinking" that lacks a more accurate analysis of the reality and its contradictions. Today, as during the Great Depression of the I930s, many people think that the crisis will have a progressive response as a logical reaction to the gravity and brutality of the current situation. However, what is already difficult may become even more complicated. At that time, massive unemployment and the resulting mobilisation amounted to fascism, genocidal nationalism and a world war. 


\section{The social impacts and the labour world}

What is even more frightening is the impact that the Covid-I9 meteor has had on society, as well as the political manipulation of the pandemic by authorities, from the international to the municipal levels. The middle class (the "enlightened" segment) went into irrational panic, withdrawn in total quarantine and ignoring large sectors of society with informal jobs - such as illegal immigrants and refugees -, which were left to their own fates. A real "every man for himself", especially in the least developed nations. The quarantine of entire populations in poor countries without consistent public policies has reached paroxysm in India. The Prime Minister warned I.4 billion people with just a few hours' notice that there would be total lockdown, generating mayhem and tension in a disoriented population.

While charlatans share recycled "analysis", spreading rumours, in the Geopolitical South parliamentarians in videoconference meetings, sometimes at night, approve reforms that will have a lasting negative social impact. Simultaneously, labour unions are forced to accept ways to make work even more flexible in order to avoid total unemployment, while a few large companies are bailed out. In the prevailing confusion, even serious people defend the anti-social and anti-labour home office, in which the employee pays the costs of work and the people lose its collective dimension. And the political struggles go on and even accelerate, while the demobilised population stays at home.

\section{Different national models put to test}

The 2020 pandemic has highlighted the existence of two groups of states: one is being efficient in managing the crisis (South Korea, China, Germany, Vietnam) and the other inefficient (the North American case is paradigmatic, not to mention the peripheral ones). Simply put, there is governmental and public health structure in the former, while the private health model has produced an unnecessary tragedy in the United States, where much of the population cannot afford its costs. In Brazil, the weakened Unified Health System (SUS) proved to be more comprehensive than the private sector, which serves a limited number of patients - many of whom will be forced to leave private health plans due to reduced income or unemployment. In Europe, there is also a difference between the mostly public model in the European Union and the British, weakened and increasingly private-owned.

Instead of focusing on absolute numbers, we should consider the per capita proportionality and the social conditions of the victims. Thus, a very 
different map would emerge. But the interesting thing is that the difference between state and market is hidden by accusations about the responsibility for the emergence or spread of the virus. The induced psychological pressure and the dominance of technological networks may obscure a more grounded judgment on the need to maintain public health networks and governments that effectively have the means to implement public policies, as opposed to the minimal or politically fragmented state. In a context of growing xenophobia, China and the immigrant are singled out as enemies - and the refugee crises have disappeared from the public debate.

\section{Perspectives}

The near disappearance of work and tourism travels, which were massive, the drastic reduction in trade, the semi-paralysis of production and the drop in consumption make the future economic scenario of globalisation uncertain. Many analysts believe that the pandemic has made room for economic and socially progressive Keynesian policies. However, their adoption depends on the political dimension, which is often negected. During the Great Depression, the United States and Germany adopted Keynesian-type policies, but with diametrically opposed means and objectives.

Is emergency aid for the unemployed sustainable for a prolonged period, and at the same time comparable to the bail out of large private corporations? The nationalisation, in whole or in part, of struggling airlines can be a way of covering private losses with public resources, only to reprivatise them afterwards. After all, most governments nowadays follow liberal policies and do not aim to use the state as the basis for a development model, but as a tool for crisis management - with the exception of China and a few other countries. Society itself, to a large extent, has absorbed a neoliberal individualistic and consumerist worldview. But what direction will their future frustrations take when it realises that the world will not be the same after the pandemic?

On the other hand, the economic crisis is leading to a massive transfer of social and national assets. There are segments that will come out of the crisis enriched while others will be ruined, due to the uneven impact of the crisis. Many countries are headed for collapse, while others stand in a better position to impose their agendas, even if relatively weakened. Mass unemployment and the new labour rules, supposedly extraordinary in order to "save jobs", can lead the neoliberal model to a kind of apotheosis, in which a frightened society will accept the current situation passively, hence the only crisis that is identifiable is the health crisis. 
Footages of streets deserted of people, but sometimes with wild animals strolling curiously, raise a contradiction that, at the same time, frightens and amazes. The crisis generated by the pandemic demonstrates that the current social model is seriously eroded and lacks the capacity for change - although it may carry on due to inertia. Nonetheless, the society is confused and frightened, which is politically dangerous. There does not seem to be an international conservative alliance, based on ideological identities, since they have conflicting material interests. On the other hand, in I50 years "progressives" have never been more fragmented and confused. This is the impasse that is raising the tensions in the world, with the virus being a mere catalyst.

There is still room for governments, for reasons of survival, to redirect their development strategies with a certain margin for manoeuvre, since the national question is returning strongly, but it may take different directions. Mega-urbanisation has proven to be counterproductive and the hedonistic and irresponsible use of nature, as a way to obtain easy profitability, is under increased criticism. The foundations for policies encouraging infrastructure projects and public works are set, but, as in I929, conflicts of interests also emerge.

Finally, the crisis can create situations of international tension caused by internal political needs which, as in the I930s, may evolve into armed conflicts. India, for example, with accelerated demographic growth and governance problems, may become an element of instability, with the aggravating aspect of its nuclear power status. Other countries do not possess the same geopolitical capacity and position. And onflicts like those in Yemen, Afghanistan and Syria have practically disappeared from the news cycle and academic discourse.

It is very likely that China will not accept a downgrade in the hierarchy of world power, and that a valued dollar will provide the United States with greater financial capacity for foreign investments without a compatible material basis. The capital would be used to acquire existing assets without generating new productive activity, unlike Asian investments in infrastructure and energy, for example, fomenting dangerous disputes in the periphery of the system. These are speculative questions, open to reflection, at a time when uncertainty prevails in international relations.

Porto Alegre, May 26 $6^{\text {th }}, 2020$.

Translated by Guilherme Thudium. 